\title{
Pelatihan Pembuatan Crunch Si Engkong Untuk Meningkatkan Pendapatan
}

\section{Crunch Si Engkong Making-Training To Increase Community Income}

\author{
Hilwa Kusno Nur Anisa ${ }^{1}$, R. Ali Pangestu ${ }^{2}$ \\ 1Program Studi Ekonomi Syariah, Fakultas Ekonomi Islam, Universitas Djuanda Bogor Jl. Tol Ciawi No. 1, Kotak \\ Pos 35 Ciawi, Bogor 16720. e-mail: hilwakusnonura@gmail.com \\ 2 Program Studi Ekonomi Syariah, Fakultas Ekonomi Islam, Universitas Djuanda Bogor Jl. Tol Ciawi No. 1, Kotak \\ Pos 35 Ciawi, Bogor 16720
}

(Diterima: 25-06-2020; Ditelaah: 25-09-2020; Disetujui: 10-02-2021)

\begin{abstract}
Abstrak
Tujuan dari pengabdian kepada masyarakat dilakukan agar masyarakat dapat memanfaatkan potensi sumber daya alam yang ada dan melimpah menjadi sebuah inovasi produk yang memiliki nilai jual, sehingga dapat meningkatkan penghasilan masyarakat Kampung Padamulya Desa Padamulya. Indikator capaian minimalnya memiliki pemahaman untuk megelola sumber daya alam yang ada dan melimpah. Target sasaran dari program pelatihan pembuatan crunch si engkong yaitu masyarakat Kampung Padamulya Desa Padamulya khususnya kalangan ibu rumah tangga. Metode yang digunakan pada pengabdian kepada masyarakat ini yaitu menggunakan metode penyuluhan dan workshop (pelatihan) tentang tata cara pembuatan produk dari singkong menjadi crunch si engkong. Hasil dari kegiatan pengabdian kepada masyarakat yaitu masyarakat memiliki antusias untuk mengetahui dan mendapatkan pengetahuan tentang pengelolaan singkong, yang dapat dilihat dari banyaknya peserta yang menginginkan tindak lanjut seperti adanya pengelompokan usaha crunch si engkong.
\end{abstract}

Kata kunci: Pelatihan, Pemanfaatan, Peningkatan Penghasilan, Singkong

\section{Abstract}

The purpose of community service is done so that the community can utilize the potential of existing and abundant natural resources to become a product innovation that has a sale value, to increase the income of the people of Padamulya Village. The minimum performance indicator understands managing existing and abundant natural resources. The target of the training program for making the crunch si engkong is the people of Padamulya Village, especially among housewives. The method used in this community service is using counseling methods and workshops (training) on procedures for making products from cassava to crunch si engkong. The results of community service activities are that the community has enthusiasm in knowing and gaining knowledge about cassava management, which can be seen from the many participants who want to follow up such as the grouping of the crunch si engkong.

Keywords: Cassava, Income Improvement, Training, Utilization

\section{PENDAHULUAN}

Kampung Padamulya merupakan salah satu wilayah di Desa Padamulya Kecamatan Pasirkuda yang masyarakatnya banyak bekerja sebagai petani. Singkong merupakan salah satu tanaman perkebunan yang paling banyak dibudidayakan di Desa Padamulya Kecamatan Pasirkuda yang terlihat dari hasil singkong yang melimpah yaitu 15 Ton/Ha atau $15 \mathrm{Kg} / \mathrm{M}^{2}$ dari lahan singkong seluas $5 \mathrm{Ha}$. Angka ini tentunya menunjukkan bahwa singkong dapat menjadi potensi utama bagi masyarakat Kampung Padamulya Desa Padamulya untuk dapat meningkatkan kesejahteraan hidup jika diolah dan dimanfaatkan sebaik-baiknya. 
Singkong mempunyai nilai tambah yang besar karena dapat digunakan sebagai bahan dasar pembuatan berbagai macam olahan makanan. Di Kampung Padamulya singkong biasanya hanya dijual langsung mentahannya atau dibuat menjadi olahan makanan keripik singkong saja, dan belum ada masyarakat yang membuat usaha olahan singkong selain keripik singkong, padahal singkong ini bisa dibuat menjadi berbagai macam olahan makanan, salah satunya crunch si engkong. Masyarakat biasanya langsung menjual singkong dengan harga Rp 2000/kg, maka jika singkong ini dibuat menjadi produk olahan crunch si engkong dapat meningkatkan harga jual singkong sehingga meningkatkan penghasilan masyakat setempat. Oleh karena itu dibutuhkan sosialisasi kepada masyarakat tentang cara mengolah singkong menjadi crunch si engkong.

Kegiatan pengabdian kepada masyarakat dengan pendekatan pengembangan potensi lokal seperti pengembangan produk singkong di Kampung Padamulya Desa Padamulya, dapat lebih meningkatkan minat masyarakat untuk terus menggali potensi dan pemanfaatan sumber daya dalam meningkatkan pendapatan dan kesejahteraan lebih mandiri, dan potensi yang ada dapat terkelola lebih optimal.

Banyak faktor yang menentukan keunggulan bersaing, salah satunya adalah dengan melakukan inovasi produk (Kurniasari, 2018). Maka dari itu, dengan melihat banyaknya singkong yang dihasilkan menjadi gagasan baru untuk melakukan inovasi dan pengembangan produk crunch si engkong.

Selanjutnya penulis melakukan pengembangan produk berupa pembuatan logo produk, pengemasan dan pemasaran, karena hal ini akan mendorong tingkat penjualan crunch si engkong. Menurut Aprindo dalam Hanifawati (2017) pada umumnya konsumen pertama kali tertarik untuk membeli makanan kemasan karena brand atau daya tarik kemasannya. Pembuatan logo produk dan pengemasan dilakukan semenarik mungkin agar menarik perhatian konsumen.

Pemasaran yang dipilih adalah pemasaran online karena pemasaran online memiliki banyak kelebihan. Seperti menurut Kotler dalam Pradiani (2017) internet marketing memiliki lima keuntungan besar bagi perusahaan yang menggunakannya. Pertama, baik perusahaan kecil maupun perusahaan besar dapat melakukannya. Kedua, tidak terdapat batas nyata dalam ruang beriklan jika dibandingkan dengan media cetak dan media penyiaran. Ketiga, akses dan pencarian keterangan sangat cepat jika dibandingkan dengan surat kilat atau bahkan fax. Keempat, situsnya dapat dikunjungi oleh siapapun, dimanapun di dalam dunia ini, kapanpun. Kelima, belanja dapat dilakukan secara lebih cepat dan sendirian.

\section{METODE PELAKSANAAN}

Metode pelaksanaan pengabdian kepada masyarakat, yaitu menggunakan metode penyuluhan dan workshop (pelatihan). Pada pelaksanaan program tersebut, ada beberapa tahap yaitu survey lokasi dan potensi lingkungan sekitar Kampung Padamulya Desa Padamulya, inovasi produk, sosialisasi inovasi produk, pelatihan produksi produk, pengemasan produk dan pemasaran produk. 
a) Survey lokasi dan potensi lingkungan sekitar Kampung Padamulya Desa Padamulya. Merupakan tahap pertama yang dilakukan secara langsung ke RT 01 RW 08 Kampung Padamulya untuk mengetahui potensi sumber daya alam yang ada di wilayah tersebut yang dapat dijadikan inovasi produk.

b) Inovasi Produk

Inovasi produk merupakan tahap kedua dari perencanaan kegiatan setelah melakukan survey lokasi dan potensi yang ada di wilayah Kampung Padamulya Desa Padamulya. Hal ini dilakukan untuk mengembangkan pemberdayaan ekonomi kreatif yang ada di Kampung Padamulya Desa Padamulya.

c) Sosialisasi Inovasi Produk

Sosialisasi inovasi produk merupakan tahap ketiga dari perencanaan kegiatan setelah inovasi produk. Sebelum adanya pelatihan produksi, dilaksanakan sosialisasi inovasi produk terlebih dahulu kepada masyarakat

d) Pelatihan Produksi Produk

Pelatihan produksi produk merupakan tahap keempat dari perencanaan kegiatan setelah sosialisai inovasi produk. Inovasi produk tersebut dipraktikkan dengan memproduksi olahan pangan hasil dari inovasi yang akan dipasarkan.

Adapun tahap produksi crunch si engkong adalah sebagai berikut:

1. Kupas kulit singkong kemudian cuci hingga bersih.

2. Parut singkong dengan ukuran sedang kemudian beri garam sedikit dan aduk rata.

3. Goreng parutan singkong tersebut hingga kuning keemasan lalu tiriskan.

4. Lelehkan cokelat batang dengan cara memanaskan air dalam panci yang pertama hingga air mendidih, dan taruh panci yang sudah terisi dengan potongan cokelat dan sedikit margarin di atas air yang mendidih (double boiler), setelah itu tunggu sambil diaduk agar cokelat bisa meleleh sempurna.

5. Masukan lelehan cokelat dan parutan singkong yang sudah di goreng tadi ke dalam satu wadah yang sama, kemudian aduk merata.

6. Masukan crunch si engkong ke dalam kertas cup kue kecil dan taburi dengan gula springkle diatasnya.

7. Kemas crunch si engkong.

e) Pengemasan Produk

Pengemasan produk merupakan tahap kelima dari perencanaan setelah pelatihan produksi produk. Tahap pengemasan dilakukan pemilihan kemasan toples plastik bening dan membuat stiker logo yang lebih menarik.

f) Pemasaran Produk

Pemasaran produk merupakan tahap keenam dari perencanaan setelah pengemasan produk. Pemasaran dilakukan dengan pemasaran online di marketplace shopee. 
Lokasi \& Waktu

Adapun lokasi yang dijadikan tempat pelaksanaannya adalah Kampung Padamulya Desa Padamulya, Kecamatan Pasirkuda, Kabupaten Cianjur, Provinsi Jawa Barat.

\section{HASIL DAN PEMBAHASAN}

Pelatihan dilakukan sebanyak 2 kali di dua tempat, masing-masing 1 kali di rumah Ibu Kasih dan rumah Ibu Amas. Jumlah peserta yang mengikuti pelatihan pertama adalah 10 orang, dan pelatihan kedua adalah 9 orang ibu rumah tangga yaitu yang tergabung dalam kelompok DKM Nurul Iman. Setelah dilakukan pelatihan maka akan dilakukan pengelompokan usaha yang ditindak lanjuti oleh ibu-ibu PKK Desa Padamulya. Hal ini dilakukan agar kegiatan berlangsung efektif dan berkelanjutan sehingga tujuan peningkatan penghasilan masyarakat dapat tercapai.

Hasil dari kegiatan pengabdian ini berupa produk "Crunch Si Engkong" yang dihasilkan oleh masyarakat dan selain itu adalah peningkatan pengetahuan masyarakat tentang pemanfaatan potensi sumber daya alam yang ada sebagai salah satu alternatif peningkatan penghasilan masyarakat.

\section{KESIMPULAN \& IMPLIKASI}

Berdasarkan hasil PKM yang telah dilaksanakan di Kampung Padamulya Desa Padamulya, Kecamatan Pasirkuda, Kabupaten Cianjur, masyarakat menyadari dan memahami bahwa potensi sumber daya alam yang ada dan melimpah dapat diolah menjadi suatu inovasi produk baru. Kegiatan pelatihan pembuatan crunch si engkong ini diharapkan dapat mengatasi permasalahan melimpahnya singkong dan mampu menggerakkan perekonomian dan meningkatkan kesejahteraan masyarakat desa.

\section{DAFTAR PUSTAKA}

Hanifawati, Tri. Any S., dan Jangkung, H. M. 2017. Pengaruh Atribut Kemasan Makanan dan Karakteristik Konsumen Terhadap Pembelian. Jurnal Agriekonomika: Jurnal Sosial Ekonomi dan Kebijakan Pertanian, Volume 6 Nomor 1. Pp 74

Kurniasari, R. D. 2018. Pengaruh Inovasi Produk, Kreativitas Produk, dan Kualitas Produk terhadap Keunggulan Bersaing. Yogyakarta.

Pradiani, T. 2017. Pengaruh Sistem Pemasaran Digital Marketing Terhadap Peningkatan Volume Penjualan Hasil Industri Rumahan. Jurnal Jibeka, Volume 11 Nomor 2. Pp 48. 